UDK 546.215:546.4/.8

\title{
INFLUENCE OF SELECTED METAL IONS ON STABILITY OF HYDROGEN PEROXIDE IN PRESENCE OF EDTA
}

\section{Utjecaj selektiranih metalnih iona na stabilnost vodik peroksida u prisustvu EDTA}

\author{
Azra Tahirović ${ }^{1}$, Kurt Kalcher $^{2}$
}

\begin{abstract}
Stability of hydrogen peroxide in time was investigated in the presence of various metal ions and a complexing agent ethylenediaminetetraacetic acid (EDTA). Metal ions: $\mathrm{Fe}(\mathrm{III}), \mathrm{Mn}(\mathrm{II}), \mathrm{Co}(\mathrm{II}), \mathrm{Cu}(\mathrm{II}), \mathrm{Ni}(\mathrm{II}), \mathrm{Zn}(\mathrm{II})$ and $\mathrm{Pb}(\mathrm{II})$ were applied at different concentrations with a chelator in a concentration of $1 \cdot 10^{-5} \mathrm{~mol} / \mathrm{dm}^{3}$, and the solutions were kept at $4^{\circ} \mathrm{C}$ between the measurements. Obtained data indicate the existence of pronounced catalytic effect for $\mathrm{Fe}(\mathrm{III}), \mathrm{Mn}(\mathrm{II}), \mathrm{Co}(\mathrm{II})$ ions on stability of hydrogen peroxide. $\mathrm{Cu}$ (II) ions showed significant catalytic influence only when applied at high concentration. $\mathrm{Ni}(\mathrm{II}), \mathrm{Pb}$ (II) and $\mathrm{Zn}$ (II) did not show significant catalytic effect on the decay of hydrogen peroxide at applied concentrations.
\end{abstract}

Key words: hydrogen peroxide, metal ions, EDTA, stability

\section{INTRODUCTION - Uvod}

Hydrogen peroxide is significant to the gas phase and aqueous chemistry of the atmosphere (GUNZ and HOFFMAN, 1990). There are strong indications that $\mathrm{H}_{2} \mathrm{O}_{2}$ is involved in the formation of $\mathrm{H}_{2} \mathrm{SO}_{4}$ and $\mathrm{HNO}_{3}$ and the corresponding salts from $\mathrm{SO}_{2}$ and $\mathrm{NO}_{\mathrm{x}}$ (CALVERT and StOCKWELL, 1983; CALVERT ET AL 1985). It can be decomposed by various aqueous chemical processes such as reaction with dissolved $\mathrm{SO}_{2}$, catalyzed destruction by transition metals, oxidation by $\mathrm{OH}$ radicals, and photolysis (ZUO and HOIGNE, 1992, 1993; GUNZ and HOFFMANN, 1990; GRAEDEL ET AL 1986; KELLY ET AL. 1985; DENG and ZUO, 1999). If decomposition is not prevented during collection or time elapsed until analysis, the measured values could underestimate the real values. ORTIZ ET AL (2003) found that peroxides incorporated in rainwater decompose with the lifetime between 2-3 $\mathrm{h}$ at room temperature, and the decomposition was influenced by the presence of metallic ions. Different approaches in stabilization of $\mathrm{H}_{2} \mathrm{O}_{2}$ in the

\footnotetext{
${ }^{1}$ Faculty of Forestry, University of Sarajevo

${ }^{2}$ Institute for Chemistry, Karl-Franzens University, Universitaetsplatz 1, A-8010 Graz, Austria
} 
samples have been used: addition of sodium stannate (SAUER ET AL 1997), stabilization with p-hydroxyphenylacetic acid (KELLY ET AL 1985), acidification and complexation (ORTIZ et al 2000). Storage of the sample at low temperatures is reported by Kok (1980), SAUER et al (1997), DENG and ZUo (1999). Most of the investigations on stability of hydrogen peroxide were carried out at room temperature with less number of investigated ions so that more kinetic measurements at lower temperature are also necessary.

Therefore, the aim of this work was to investigate influence of selected transition metal ions on stability of hydrogen peroxide in presence of a chelator EDTA in synthetic solutions kept at $4^{\circ} \mathrm{C}$. Investigations were carried out with solutions containing $200 \mu \mathrm{g} / \mathrm{dm}^{3}$ of hydrogen peroxide, EDTA $\left(1 \cdot 10^{-5} \mathrm{~mol} / \mathrm{dm}^{3}\right)$ and metal ions applied at three different concentrations. $\mathrm{Co}(\mathrm{II}), \mathrm{Mn}(\mathrm{II}), \mathrm{Fe}(\mathrm{III}), \mathrm{Ni}(\mathrm{II}), \mathrm{Cu}(\mathrm{II}), \mathrm{Pb}$ (II), $\mathrm{Zn}$ (II) were used and their influence on the stability of the analyte was monitored in time. Chemiluminescence sensors based on the Co(II) catalyzed reaction of luminol with hydrogen peroxide were used for the investigations. This work presents second part of investigations on the influence of transition metal ions on decay of hydrogen peroxide in aqueous solutions stored at $4^{\circ} \mathrm{C}$.

\section{MATERIALS AND METHODS - Materijali i metode}

\section{Solutions and reagents - Otopine i reagensi}

All reagents were analytical grade, obtained from Fluka and Merck. All chemicals were used as received.

A stock solution of hydrogen peroxide $\left(10,000 \mathrm{mg} / \mathrm{dm}^{3}\right)$ was prepared by diluting the necessary amount of standardized $30 \%$ hydrogen peroxide to $30 \mathrm{~cm}^{3}$ with water. Standard solutions of lower concentrations were prepared daily by appropriate dilution of the stock before use. All solutions were stored in the dark at $4^{\circ} \mathrm{C}$.

Stock solutions of cobalt chloride $\left(0.1 \mathrm{~mol} / \mathrm{dm}^{3}\right)$, luminol $\left(56.4 \mathrm{mmol} / \mathrm{dm}^{3}\right)$, and sodium lauryl sulphate were prepared according to TAHIROVIĆ ET. AL (2007).

Stock solutions of metal ions were prepared in concentrations of 1000 $\mathrm{mg} / \mathrm{dm}^{3}$. Working solutions were prepared daily before use. Solutions were kept in the refrigerator at $4^{\circ} \mathrm{C}$ between the measurements.

$0.1 \mathrm{~mol} / \mathrm{dm}^{3}$ solution of ethylenediaminetetraacetic acid (EDTA) was prepared by dissolving $1.8615 \mathrm{~g}$ of $\mathrm{Na}_{2} \mathrm{H}_{2} \mathrm{Y} \times 2 \mathrm{H}_{2} \mathrm{O}$ in water. The solution was kept at $4^{\circ} \mathrm{C}$. Distilled, deionized water (Milli-Q, USA) was used for preparation of all solutions.

\section{Analytical method - Analitička metoda}

A method based on the chemiluminescence reaction of hydrogen peroxide with luminol under alkaline conditions in the presence of $\mathrm{Co}$ (II) ions as a catalyst was 
used. Disposable low-cost chemical sensors designed for single use were constructed according to TAHIROVIĆ ET AL (2007). The membranes were prepared by dispensing 10 $\mathrm{cm}^{3}$ of polymer solution containing hydroxyethyl cellulose $(1.5 \mathrm{~m} / \mathrm{v})$, cobalt chloride $\left(1 \mathrm{mmol} / \mathrm{dm}^{3}\right)$ and sodium lauyril sulphate $\left(400 \mathrm{mg} / \mathrm{dm}^{3}\right)$ on a microscope cover glass. Luminol and sodium phosphate are mixed to the analyte solution with a metal ion and EDTA prior to analysis. Measurements were done at $25^{\circ} \mathrm{C}$.

Chemiluminescence determinations of $\mathrm{H}_{2} \mathrm{O}_{2}$ were carried out by the homemade luminometer with a photodiode detector. The device was connected to a personal computer with an in house-written software. $10 \mu \mathrm{L}$ of sample volume was dispensed onto the polymer membrane with a micropipette placed directly on the photodiode. The peak area of the measured signal for 100 points was used for the evaluation of the results. The two channels with highest sensitivity were used and the signals were monitored in dependence of time. Results are expressed as concentration decrease $(\%)$ versus time.

\section{Investigation of stability of hydrogen peroxide - Ispitivanje stabilnosti vodik peroksida}

Experiments were carried out with solutions $\left(200 \mathrm{~cm}^{3}\right)$ containing hydrogen peroxide $\left(200 \mu \mathrm{g} / \mathrm{dm}^{3}\right)$ and appropriate concentrations of the investigated metal ions $\left(200 \mu \mathrm{g} / \mathrm{dm}^{3}, 1000 \mu \mathrm{g} / \mathrm{dm}^{3}\right.$ and $\left.2000 \mu \mathrm{g} / \mathrm{dm}^{3}\right)$. EDTA was added before the addition of the analyte in a concentration of $1 \cdot 10^{-5} \mathrm{~mol} / \mathrm{dm}^{3}$. At the same time, blank solutions containing corresponding concentration of investigated ions, and EDTA were included. Standard solutions of $\mathrm{H}_{2} \mathrm{O}_{2}$ with EDTA were also used to compare with the obtained data. All samples were kept at $4^{\circ} \mathrm{C}$ between the measurements.

Test solutions were prepared by adding luminol $\left(1.4 \mathrm{mmol} / \mathrm{dm}^{3}\right)$ and sodium phosphate $\left(53 \mathrm{mmol} / \mathrm{dm}^{3}\right)$ to $10 \mathrm{~mL}$ of the previously prepared solutions of the analyte with metal ions and EDTA. A home-made portable luminometer (Institute for chemistry, Karl-Franzens University, Graz, Austria) was used for the measurements of chemiluminescence.

\section{RESULTS - Rezultati}

Stability of aqueous solutions of hydrogen peroxide in concentration of 200 $\mu \mathrm{g} / \mathrm{dm}^{3}$ with EDTA was investigated. Solutions were prepared according to above mentioned procedures and kept in refrigerator at $4^{\circ} \mathrm{C}$. All solutions contained 200 $\mu \mathrm{g} / \mathrm{dm}^{3}$ of $\mathrm{H}_{2} \mathrm{O}_{2}$. Influence of $\mathrm{Fe}(\mathrm{III}), \mathrm{Mn}(\mathrm{II}), \mathrm{Cu}(\mathrm{II}), \mathrm{Co}(\mathrm{II}), \mathrm{Ni}(\mathrm{II}), \mathrm{Zn}(\mathrm{II})$ and $\mathrm{Pb}(\mathrm{II})$ ions was investigated in concentrations of $200 \mu \mathrm{g} / \mathrm{dm}^{3}, 1000 \mu \mathrm{g} / \mathrm{dm}^{3}$, and 2000 $\mu \mathrm{g} / \mathrm{dm}^{3}$. EDTA was added in the solutions in a concentration of $1 \cdot 10^{-5} \mathrm{~mol} / \mathrm{dm}^{3}$. Obtained results are presented in Figure 1. 


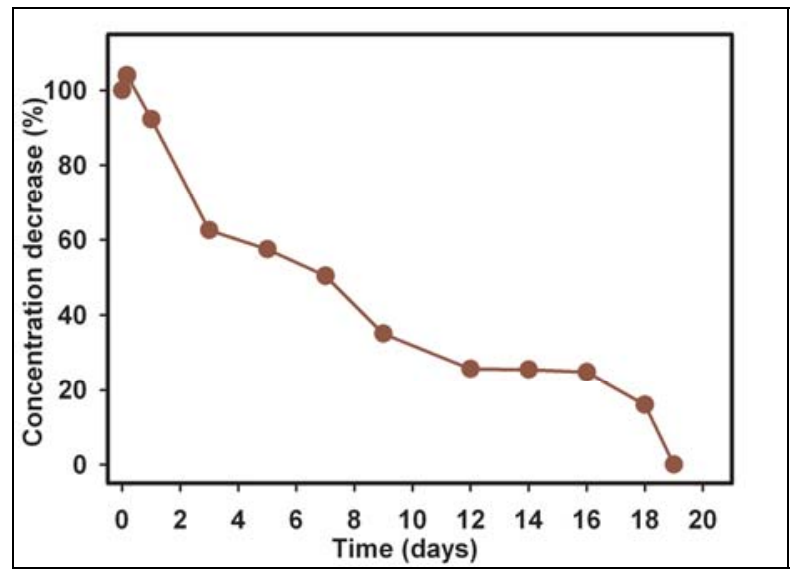

Figure 1. Decomposition of hydrogen peroxide $\left(200 \mu \mathrm{g} / \mathrm{dm}^{3}\right)$ in the presence of EDTA $\left(1 \cdot 10^{-5}\right.$ $\left.\mathrm{mol} / \mathrm{dm}^{3}\right)$.

Slika 1. Razlaganje vodik peroksida $\left(200 \mu \mathrm{g} / \mathrm{dm}^{3}\right)$ u prisustvu EDTA $\left(1 \cdot 10^{-5} \mathrm{~mol} / \mathrm{dm}^{3}\right)$.

Concentration of the analyte was diminished by $20 \%$ after 1 day and by $50 \%$ after 7 days. Complete disintegration of the analyte requires about 19 days.

The effect of $\mathrm{Mn}$ (II) ions on the decomposition of $\mathrm{H}_{2} \mathrm{O}_{2}$ in the solutions containing EDTA $\left(1 \cdot 10^{-5} \mathrm{~mol} / \mathrm{dm}^{3}\right)$ is displayed in Figure $2 . \mathrm{H}_{2} \mathrm{O}_{2}$ in solutions with $200 \mu \mathrm{g} / \mathrm{dm}^{3}$ of $\mathrm{Mn}$ (II) is decomposed completely after 11 days; with $1000 \mu \mathrm{g} / \mathrm{dm}^{3}$ of $\mathrm{Mn}$ (II) ions after 8 days, and with $2000 \mu \mathrm{g} / \mathrm{dm}^{3} \mathrm{Mn}(\mathrm{II})$ after 7 days.

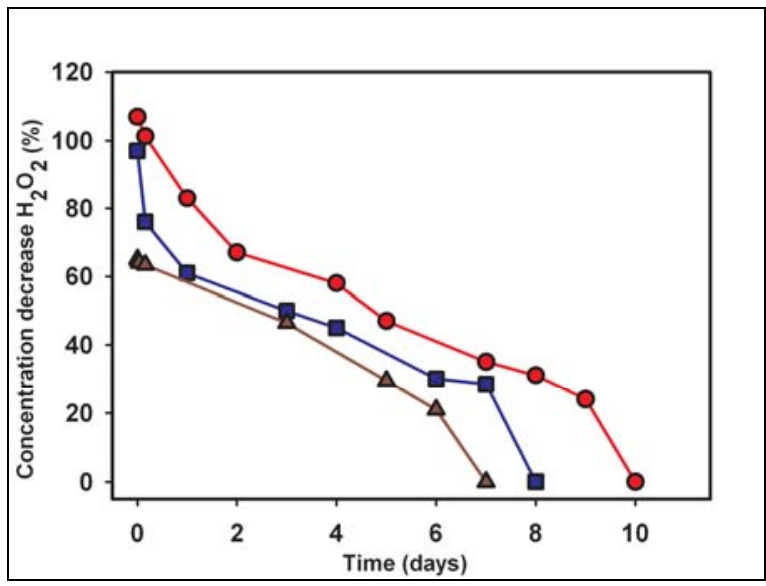

Figure 2. Influence of Mn(II) ions on decay of hydrogen peroxide $\left(200 \mu \mathrm{g} / \mathrm{dm}^{3}\right)$ in presence of EDTA $\left(1 \cdot 10^{-5} \mathrm{~mol} / \mathrm{dm}^{3}\right) ;(\bullet) 200 \mu \mathrm{g} / \mathrm{dm}^{3} \mathrm{Mn}(\mathrm{II}) ;(\mathbf{\square}) 1000 \mu \mathrm{g} / \mathrm{dm}^{3} \mathrm{Mn}(\mathrm{II}) ;(\boldsymbol{\Delta}) 2000 \mu \mathrm{g} / \mathrm{dm}^{3} \mathrm{Mn}$ (II).

Slika 2. Utjecaj Mn (II) iona na razlaganje vodik peroksida $\left(200 \mu \mathrm{g} / \mathrm{dm}^{3}\right)$ u prisustvu EDTA

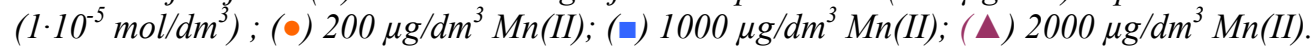

The decay of $\mathrm{H}_{2} \mathrm{O}_{2}$ in the presence of $\mathrm{Fe}(\mathrm{III})$ ions with EDTA is shown in Figure 3. 


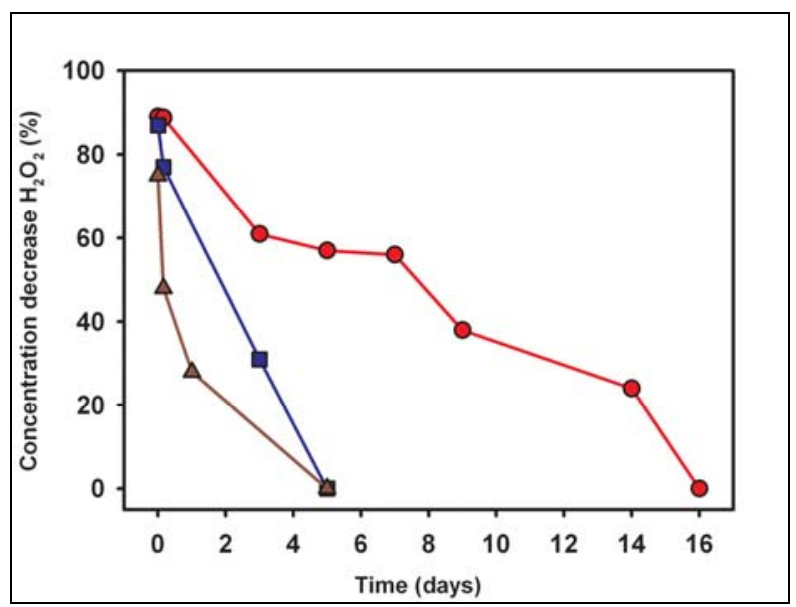

Figure 3. Influence of Fe(III) ions on decay of hydrogen peroxide $\left(200 \mu \mathrm{g} / \mathrm{dm}^{3}\right)$ in presence of EDTA $\left(1 \cdot 10^{-5} \mathrm{~mol} / \mathrm{dm}^{3}\right)$; (•) $200 \mu \mathrm{g} / \mathrm{dm}^{3} \mathrm{Fe}(\mathrm{III}) ;(\square) 1000 \mu \mathrm{g} / \mathrm{dm}^{3} \mathrm{Fe}(\mathrm{III}),(\Delta) 2000 \mu \mathrm{g} / \mathrm{dm}^{3} \mathrm{Fe}(\mathrm{III})$.

Slika 3. Utjecaj Fe(III) iona na razlaganje vodik peroksida $\left(200 \mu \mathrm{g} / \mathrm{dm}^{3}\right)$ u prisustvu EDTA

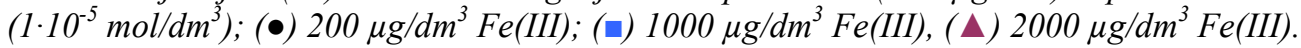

The decomposition of the analyte in the presence of $200 \mu \mathrm{g} / \mathrm{dm}^{3} \mathrm{Fe}(\mathrm{III})$ was very similar to hydrogen peroxide and EDTA alone, $\mathrm{H}_{2} \mathrm{O}_{2}$ will be disintegrated in 16 days. With higher concentration of $\mathrm{Fe}(\mathrm{III})$ ions $\left(1000\right.$ and $\left.2000 \mu \mathrm{g} / \mathrm{dm}^{3}\right)$ fast decomposition occurs and accomplished within 5 days.

Influence of $\mathrm{Co}$ (II) ions at different concentrations in the presence of EDTA was also investigated and the results are shown in Figure 4.

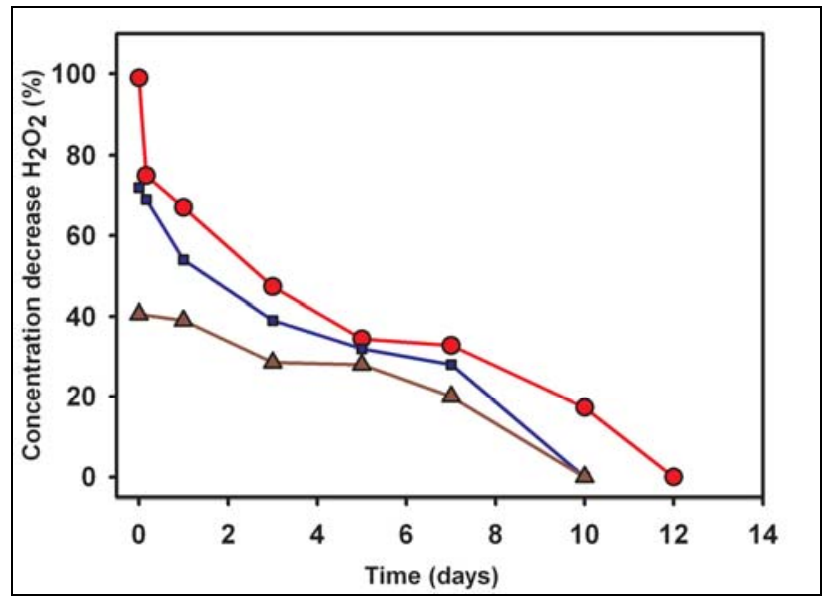

Figure 4. Influence of Co(II) ions on decay of hydrogen peroxide $\left(200 \mu \mathrm{g} / \mathrm{dm}^{3}\right)$ in the presence of EDTA $\left(1 \cdot 10^{-5} \mathrm{~mol} / \mathrm{dm}^{3}\right) ; 200 \mu \mathrm{g} / \mathrm{dm}^{3}$ (•) Co(II); ( ( ) $1000 \mu \mathrm{g} / \mathrm{dm}^{3} \mathrm{Co}(\mathrm{II}),(\Delta) 2000 \mu \mathrm{g} / \mathrm{dm}^{3} \mathrm{Co}$ (II).

Slika 4. Utjecaj Co(II) iona na razlaganje vodik peroksida $\left(200 \mu \mathrm{g} / \mathrm{dm}^{3}\right)$ u prisustvu EDTA

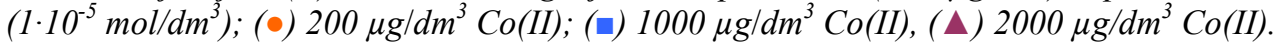


With increasing concentrations of $\mathrm{Co}(\mathrm{II})$ ions the signals of the analyte decrease more rapidly. $\mathrm{H}_{2} \mathrm{O}_{2}$ in solutions containing $200 \mu \mathrm{g} / \mathrm{dm}^{3} \mathrm{Co}(\mathrm{II})$ ions was completely degraded after 12 days, and with $1000 \mu \mathrm{g} / \mathrm{dm}^{3}$ and $2000 \mu \mathrm{g} / \mathrm{dm}^{3} \mathrm{Co}$ (II) after 10 days. The decrease of the signal for the analyte at two higher concentrations is significant.

Figure 5. shows the effect of $\mathrm{Ni}(\mathrm{II})$ ions on the decomposition of hydrogen peroxide in the presence of EDTA.

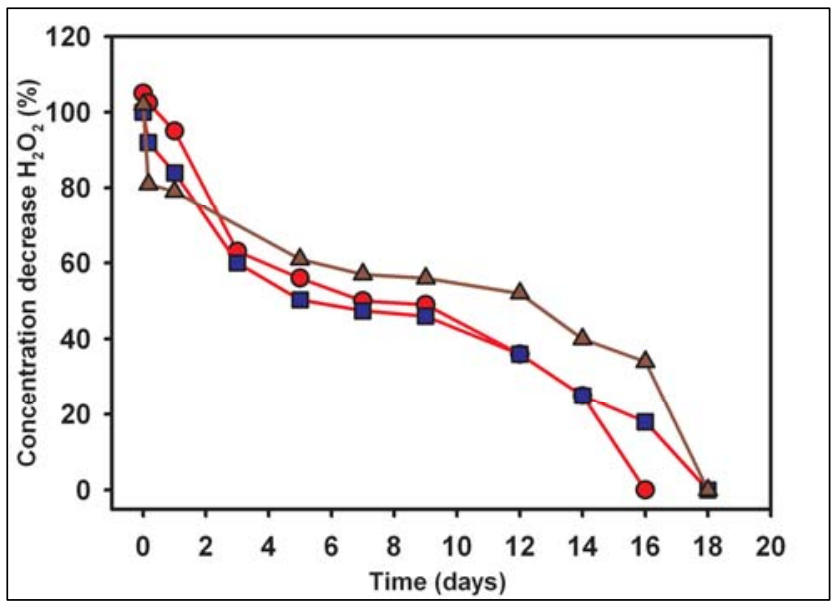

Figure 5. Influence of $\mathrm{Ni}(\mathrm{II})$ ions on the decomposition of hydrogen peroxide $\left(200 \mu \mathrm{g} / \mathrm{dm}^{3}\right)$ in

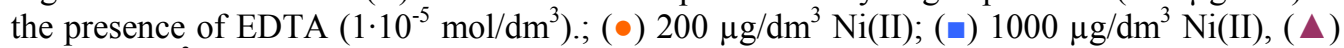
$2000 \mu \mathrm{g} / \mathrm{dm}^{3} \mathrm{Ni}(\mathrm{II})$.

Slika 5. Utjecaj Ni(II) iona na razlaganje vodik peroksida $\left(200 \mu \mathrm{g} / \mathrm{dm}^{3}\right)$ u prisustvu EDTA

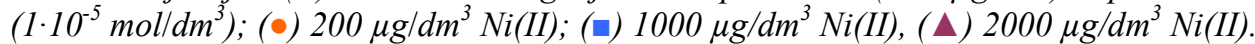

All three curves are very similar although the signals of $200 \mu \mathrm{g} / \mathrm{dm}^{3}$ and 1000 $\mu \mathrm{g} / \mathrm{dm}^{3}$ of the ions resemble even more. The total decomposition is accomplished after some 18 days for Ni (II) concentrations of $200 \mu \mathrm{g} / \mathrm{dm}^{3}$ and $1000 \mu \mathrm{g} / \mathrm{dm}^{3}$, and after 16 days for the concentration of $2000 \mu \mathrm{g} / \mathrm{dm}^{3}$.

The influence of $\mathrm{Zn}(\mathrm{II})$ and EDTA on the disintegration of $\mathrm{H}_{2} \mathrm{O}_{2}$ is presented in Figure 6. For all three concentrations the graphs are practically identical and very similar to the graph obtained for the solution of $\mathrm{H}_{2} \mathrm{O}_{2}$ with EDTA only. The total decomposition of $\mathrm{H}_{2} \mathrm{O}_{2}$ is accomplished after 16 days. 


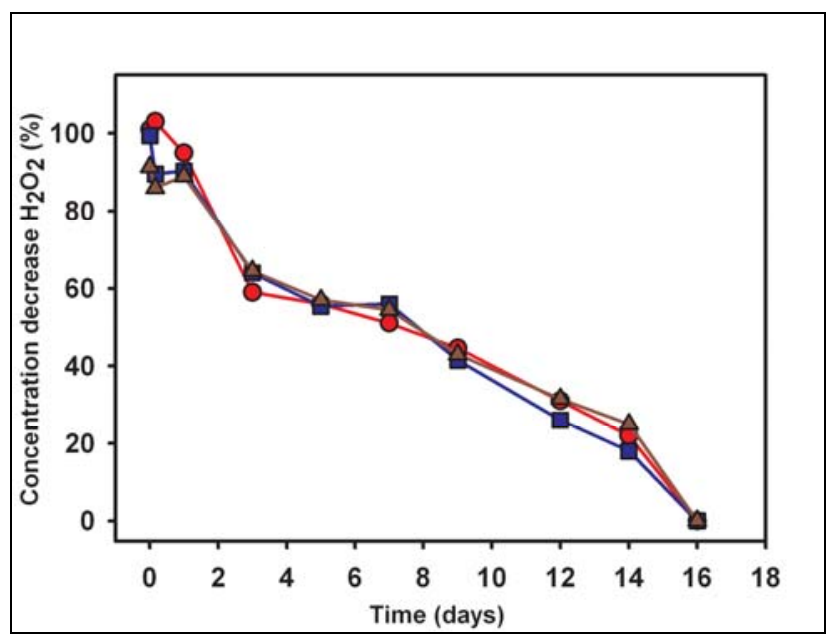

Figure 6. Influence of $\mathrm{Zn}(\mathrm{II})$ ions on decay of hydrogen peroxide $\left(200 \mu \mathrm{g} / \mathrm{dm}^{3}\right)$ in the presence of EDTA $\left(1 \cdot 10^{-5} \mathrm{~mol} / \mathrm{dm}^{3}\right)$; (•) $200 \mu \mathrm{g} / \mathrm{dm}^{3} \mathrm{Zn}(\mathrm{II})$; (甘) $1000 \mu \mathrm{g} / \mathrm{dm}^{3} \mathrm{Zn}(\mathrm{II}),(\boldsymbol{\Delta}) 2000 \mu \mathrm{g} / \mathrm{dm}^{3}$ $\mathrm{Zn}(\mathrm{II})$.

Slika 6. Utjecaj Zn(II) iona na razlaganje vodik peroksida $\left(200 \mu \mathrm{g} / \mathrm{dm}^{3}\right)$ u prisustvu EDTA

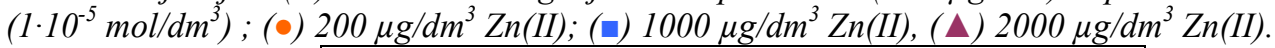

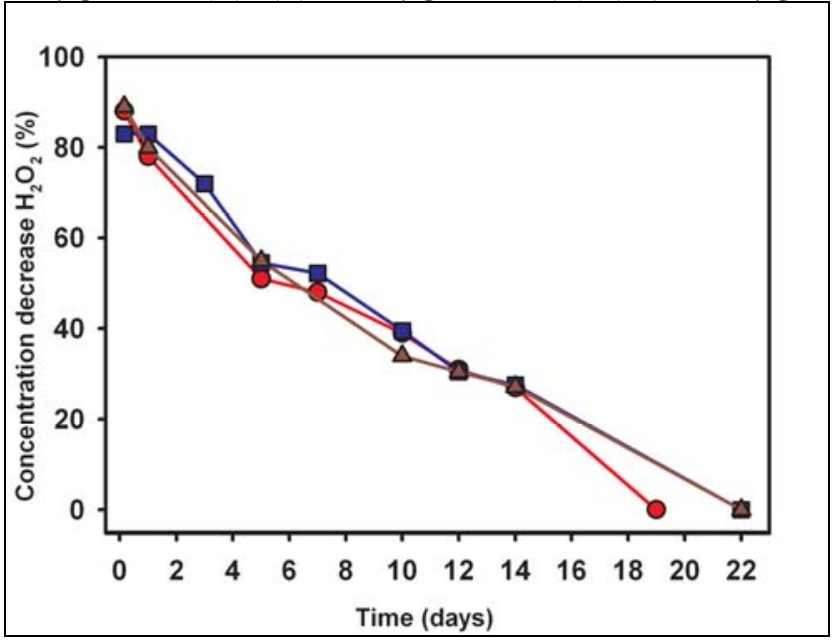

Figure 7. Influence of $\mathrm{Pb}$ (II) ions on decay of hydrogen peroxide $\left(200 \mu \mathrm{g} / \mathrm{dm}^{3}\right)$ in the presence of EDTA (1·10 $\left.0^{-5} \mathrm{~mol} / \mathrm{dm}^{3}\right) ;(\bullet) 200 \mu \mathrm{g} / \mathrm{dm}^{3} \mathrm{~Pb}$ (II); (

Slika 7. Utjecaj Pb(II) iona na razlaganje vodik peroxida $\left(200 \mu \mathrm{g} / \mathrm{dm}^{3}\right)$ u prisustvu EDTA

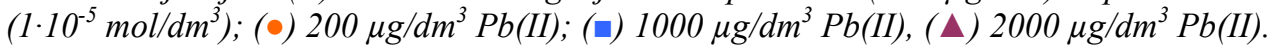

Similar results were obtained with $\mathrm{Pb}(\mathrm{II})$ in the presence of EDTA, with an even more dilating effect on the decomposition of $\mathrm{H}_{2} \mathrm{O}_{2}$ than $\mathrm{Zn}$ (II) (Figure 7). 
The signals for all three concentrations of $\mathrm{Pb}(\mathrm{II})$ ions were decreasing identically up to 15 days. After that there was a small difference between the lowest concentration of $\mathrm{Pb}(\mathrm{II})$ and the remaining two higher concentrations.

The effect of $\mathrm{Cu}(\mathrm{II})$ ions in the presence of EDTA was investigated only with two concentrations, 200 and $1000 \mu \mathrm{g} / \mathrm{dm}^{3}$, since $2000 \mu \mathrm{g} / \mathrm{dm}^{3}$ of $\mathrm{Cu}$ (II) ions suppressed the signal completely after addition to the solution of hydrogen peroxide even in presence of EDTA. Decomposition of the analyte with two investigated concentrations was finished in 19 and 14 days respectively. The results are shown in Figure 8 .

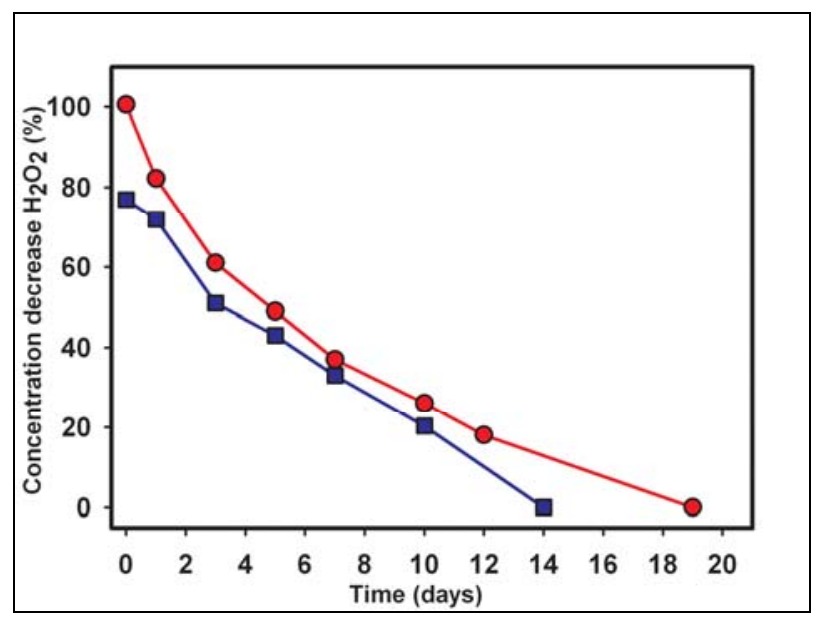

Figure 8. Influence of $\mathrm{Cu}$ (II) ions on decay of hydrogen peroxide $\left(200 \mu \mathrm{g} / \mathrm{dm}^{3}\right)$ in presence of EDTA $\left(1 \cdot 10^{-5} \mathrm{~mol} / \mathrm{dm}^{3}\right) ;(\bullet) 200 \mu \mathrm{g} / \mathrm{dm}^{3} \mathrm{Cu}(\mathrm{II}) ;(-) 1000 \mu \mathrm{g} / \mathrm{dm}^{3} \mathrm{Cu}(\mathrm{II})$.

Slika 8. Utjecaj Cu(II) iona na razlaganje vodik peroksida $\left(200 \mu \mathrm{g} / \mathrm{dm}^{3}\right)$ u prisustvu EDTA

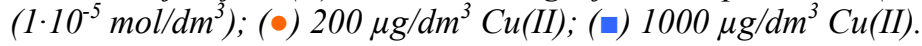

\section{DISCUSSION - Diskusija}

It is know that the decomposition of hydrogen peroxide and its reaction with inorganic are catalyzed by transition metal ions or their complexes in both heterogeneous and homogeneous systems (HABER and WEISS, 1934; GLASNER, 1959; KREMER, 1985).

Two mechanisms were suggested for these reactions. The first is a radical chain mechanism for transition metal ions which have two available oxidation states $(\mathrm{Cu}, \mathrm{Fe}, \mathrm{Co}, \mathrm{Mn})$. The second mechanism is that hydrogen peroxide reacts with metal species to form an intermediate complex, $\mathrm{M}^{\mathrm{n}+}-\mathrm{H}_{2} \mathrm{O}_{2}$ which can decompose into $\mathrm{O}_{2}$ and the original metal species (AUGUSTI ET AL 1998).

These investigations deal with the stability of hydrogen peroxide solutions containing different amounts of interfering metal ions. The solutions were kept at $4^{\circ} \mathrm{C}$ 
and the signals were monitored in dependence of time. All previously checked ions were investigated in the presence of a complexing agent, EDTA $\left(1 \cdot 10^{-5} \mathrm{~mol} / \mathrm{L}\right)$ and solutions contained $200 \mu \mathrm{g} / \mathrm{dm}^{3}$ of $\mathrm{H}_{2} \mathrm{O}_{2}$. Each ion was investigated in concentrations of $200 \mu \mathrm{g} / \mathrm{dm}^{3}, 1000 \mu \mathrm{g} / \mathrm{dm}^{3}$ and $2000 \mu \mathrm{g} / \mathrm{dm}^{3}$. For each test solution, a blank solution was prepared containing corresponding concentration of investigated ion, and complexing agent for experiments where EDTA was included. They were kept under the same conditions as the test solutions.

$\mathrm{H}_{2} \mathrm{O}_{2}$ added to ultra pure water with EDTA is extremely stable with total decomposition time of 19 days. Also addition of EDTA does not prevent the peroxide degradation in the solution (Figure 1).

Generally, we can notice that in presence of EDTA following ions catalyse the decay of hydrogen peroxide at higher concentrations: $\mathrm{Fe}(\mathrm{III})>\mathrm{Mn}(\mathrm{II})>\mathrm{Co}(\mathrm{II})$. The influence of Co (II) is pronounced at the beginning just after the addition of the ions, whereas the influences of $\mathrm{Fe}(\mathrm{III})$ and $\mathrm{Mn}$ (II) ions are more pronounced in the course of decaying. The data show that the influence by manganese can be reduced significantly but can not be removed completely with the addition of EDTA (Figure 2).

When comparing these data with the decomposition of hydrogen peroxide in the presence of $\mathrm{Fe}(\mathrm{III})$ without a complexing agent it can be seen that the decomposition is generally faster when EDTA was present (TAHIROVIĆ, 2006). With $1000 \mu \mathrm{g} / \mathrm{dm}^{3}$ of $\mathrm{Fe}$ (III) during the first two days the decomposition of hydrogen peroxide is slower, but after that it was increased. Much faster disintegration was observed in solutions with $2000 \mu \mathrm{g} / \mathrm{dm}^{3}$ of Fe(III) ions (Figure 3). Thus, EDTA seems to be an oxidizable substrate, which might favour the decay of $\mathrm{H}_{2} \mathrm{O}_{2}$ in case that there is still sufficient catalyst present to promote of the analyte. Some investigators found that iron complexes of EDTA (1:1) induce the catalytic reduction of hydrogen peroxide (ENGELMANN ET AL 2003). It was stated that the addition of EDTA may enhance the oxidative processes if the ligand-to-metal-ratio is low, less than one whereas the rates of progressive oxidative processes may decrease if the ratio, along with the relative amount of hydrogen peroxide, is high (excess ligand). This is full in agreement with our observations.

When EDTA is present in solutions containing $\mathrm{Co}(\mathrm{II})$ and $\mathrm{H}_{2} \mathrm{O}_{2}$, a stable complex is formed which delays the catalytic activity of $\mathrm{Co}$ (II) ions to significantly. As there is some amount of uncomplexed Co(II) ions due to a limited concentration of EDTA in the solution, it is expected that higher concentrations of Co(II) ions will exert a more pronounced catalytic effect on the analyte. As a consequence, it is important to notice that the decrease of the signal of hydrogen peroxide after addition of the Co(II) ions at concentrations of $1000 \mu \mathrm{g} / \mathrm{dm}^{3}$ and $2000 \mu \mathrm{g} / \mathrm{dm}^{3}$ to the solutions of hydrogen peroxide is still significant, despite the presence of EDTA (Figure 4).

$\mathrm{Ni}(\mathrm{II})$ at all investigated concentrations did not show any influence on the decomposition of hydrogen peroxide. There is not much significant difference between the decomposition of hydrogen peroxide in presence of various $\mathrm{Ni}$ (II) concentrations during the first ten days (Figure 5). 
For all three concentrations of $\mathrm{Zn}(\mathrm{II})$ ions the graphs are practically identical and very similar to the signals obtained for the solution of $\mathrm{H}_{2} \mathrm{O}_{2}$ with EDTA only (Figure 6). Similar results were obtained with $\mathrm{Pb}(\mathrm{II})$ in the presence of EDTA, with an even more dilating effect on the decomposition of $\mathrm{H}_{2} \mathrm{O}_{2}$ than $\mathrm{Zn}$ (II) (Figure 7). Also these data here again underline the fact that $\mathrm{Pb}(\mathrm{II})$ could exert a slightly stabilizing effect on hydrogen peroxide. The reason could be very similar to $\mathrm{Zn}(\mathrm{II})$, also considering the fact that $\mathrm{Pb}(\mathrm{IV})$ is not a convenient partner for a suitable redox couple to act as a catalyst for the decomposition of $\mathrm{H}_{2} \mathrm{O}_{2}$, because of its high oxidation potential. The exact reason for the slightly stabilizing effect of $\mathrm{Zn}(\mathrm{II})$ is not yet clear, but probably some comlexation of the analyte may occur, where the complex seems to be more stable than the free $\mathrm{H}_{2} \mathrm{O}_{2}$. The lack of catalytic activity of $\mathrm{Zn}^{2+}$ lies in its electronic configuration, which favors only +2 as a proper oxidation state without the possibility to form an electrochemically active redox couple in solution.

From the obtained results it can be seen that the addition of EDTA suppresses the catalytic effect of $\mathrm{Cu}$ (II) on the decomposition with both investigated concentrations probably due to the change in the redox potential of $\mathrm{Cu}(\mathrm{II})$ ions as a result of ligation with EDTA (Figure 8).

Generally, we may conclude that EDTA will extend the stability of $\mathrm{H}_{2} \mathrm{O}_{2}$ in the presence of transition metal ions. It must be also mentioned that lower concentrations of $\mathrm{H}_{2} \mathrm{O}_{2}$ are much more sensitive to interferences than higher concentrations, even in the presence of complexing agent.

\section{REFERENCES - Literatura}

Augusti, R., Dias, A.O., Rocha L.L., Lago, R.M. (1998): Kinetics and Mechanism of Benzene Derivative Degradation with Fenton's Reagent in Aqueous Medium Studied by MIMS. Journal of Physical Chemistry, 102: pp. 10723-10727. Calvert, J.G., StockWell, W.R. (1983): Acid Generation in Troposphere by Gas Phase Chemistry. Environmental Science and Technology, 17: pp. 428-443.

Calvert, J.G., Lazarus A., Kok, G.L., Heikes B.G., Walege, J.G., Lind, J., Cantrell, L.A. (1985): Chemical Mechanisms of Acid Generation in the Troposphere. Nature, 17: pp. 27-35.

Deng, Y., Zuo, Y. (1999): Factors Affecting the Levels of Hydrogen Peroxide in Rainwater. Atmospheric Environment, 33(9): pp. 1469-1478. DOI: http://dx.doi.org/10.1016/S1352-2310(98)00239-8.

Engelmann, M.D., Bobier, R.T., Hiatt, T., Cheng, I.F. (2003). Variability of the Fenton Reaction Characteristics of EDTA, DTPA, and Citrate Complexes of Iron. Biometals, 16(4): pp. 519-27. DOI: 10.1023/A:1023480617038. 
Haber, F., Weiss, J. (1934): The Catalytic Decomposition of Hydrogen Peroxide by Iron Salts. Proceedings of the Royal Society A, 147: pp. 332-351.

Graedel, T.E., Mandich, M.L., Weschler, C.J. (1986): Kinetic Model Studies of Atmospheric Droplet Chemistry 2. Homogeneous Transition Metal Chemistry in Raindrops. Journal of Geophysical Research, 91(D4): pp. 5205-5221.

Glasner, A. (1959): The Constitution of Copper Peroxide and the Catalytic Decomposition of Hydrogen Peroxide. Journal of the Chemical Society: 24642467.

Gunz, D.W., Hoffmann, M.R. (1990): Atmospheric Chemistry of Peroxides: a Review. Atmospheric Environment A, 24 (7): pp. 1601-1633.

Kelly, T.J., Daum, P.H., Schwartz, S.E. (1985): Measurements of Peroxides in Cloudwater and Rain. Journal of Geophysical Research, 90(D5): pp. 7861-7871.

KREMeR, M. (1985): Complex" Versus "Free Radical" Mechanism for the Catalytic Decomposition of $\mathrm{H}_{2} \mathrm{O}_{2}$ by Ferric Ions. International Journal of Chemical Kinetic, 17(12): pp. 1299-1314.

KOK G L, (1980): Measurements of Hydrogen Peroxide in Rainwater. Atmospheric Environment, 14(6): pp. 653-656.

Ortiz, V., RuBio, M.A., Lissi, E.A. (2000): Hydrogen Peroxide Deposition and Decomposition in Rain and Dew Waters. Atmospheric Environment, 34(7): pp. 1139-1146. DOI: http://dx.doi.org/10.1016/S1352-2310(99)00345-3.

Sauer F, Limbach S, Moortgat G K. (1997): Measurements of Hydrogen Peroxide and Individual Organic Peroxides in the Marine Troposphere. Atmospheric Environment, 31(8): pp. 1173-1184. http://dx.doi.org/10.1016/S13522310(96)00289-0.

Sedlak D L, Hoigne J, David M M, Colvile R N, Seyffer E, Acker K, Wiepercht W, LIND J A, FuzzI S. (1997): The Cloudwater Chemistry of Iron and Copper at Great Dun Fell, U.K. Atmospheric Environment, 31(16): pp. 2515-2526. http://dx.doi.org/10.1016/S1352-2310(96)00080-5.

TAhiRović, A., Čopra, A., OMANOVIĆ-MIKLIČAnIN, E., KALCher, K. (2007): A Chemiluminescence Sensor for the Determination of Hydrogen Peroxide. Talanta, 72(4): pp. 1378-1385.DOI: http://dx.doi.org/10.1016/j.talanta.2007.01.072.

TAHIROVIĆ, A., Čopra-JANIĆIJEVIĆ, A., KALCHER, K. (2009): Ispitivanje stabilnosti vodik peroksida u sintetičkim i realnim uzorcima kišnice. Radovi hrvatskog društva za znanost i umjetnost, XI: pp. 197-207. 
Zuo, Y., HoIgne, J. (1992): Formation of $\mathrm{H}_{2} \mathrm{O}_{2}$ and Depletion of Oxalic Acid in Atmospheric Water by Photolysis of Iron(III) Oxalate Complexes. Environmental Science and Technology, 2: pp. 1014-1022.

Zuo, Y., Holgne, J. (1993): Evidence for Photochemical Formation of $\mathrm{H}_{2} \mathrm{O}_{2}$ and Oxidation of $\mathrm{SO}_{2}$ in Authentic Fog Water. Science, 260(5104): pp. 71-73.

\section{SAŽETAK}

U radu su prikazani rezultati ispitivanja stabilnosti vodik peroksida u prisustvu različitih iona prelaznih metala i kompleksirajućeg sredstva, etilendiamintetraacetatne kiseline (EDTA). U ispitivanjima su korišteni ioni $\mathrm{Fe}(\mathrm{III}), \mathrm{Mn}(\mathrm{II}), \mathrm{Co}(\mathrm{II}), \mathrm{Cu}(\mathrm{II})$, $\mathrm{Ni}(\mathrm{II}), \mathrm{Pb}(\mathrm{II})$ i $\mathrm{Zn}(\mathrm{II})$ a primjenjivani su pojedinačno. Ioni su aplicirani $\mathrm{u}$ koncentracijama od 200, 1000 i $2000 \mu \mathrm{g} / \mathrm{dm}^{3}$ uz dodatak EDTA $\left(1 \cdot 10^{-5} \mathrm{~mol} / \mathrm{dm}^{3}\right)$ i vodik peroksida $\left(200 \mu \mathrm{g} / \mathrm{dm}^{3}\right)$. Za svaku ispitivanu otopinu korištena je odgovarajuća slijepa proba, koja je sadržala sve komponente izuzev analita. Otopine su čuvane na $4^{\circ} \mathrm{C}$ između mjerenja i praćena je promjena koncentracije analita u vremenu. Sva mjerenja su vršena na $25^{\circ} \mathrm{C}$. Rezultati su izraženi kao procentualna promjena koncentracije vodik peroksida u vremenu.

Za praćenje signala analita korišten je prenosivi luminometar, konstruisan u laboratoriji Instituta za kemiju (Karl-Franzens Univerzitet). Detekcija analita je zasnovana na reakciji vodik peroksida i luminola u baznoj sredini, kataliziranoj $\mathrm{Co}$ (II) ionima u prisusutvu tenzida, natrij lauril sulfata. Mjerenja su vršena upotrebom kemiluminiscentnih senzora na bazi prethodno opisane reakcije (TAHIROVIĆ ET AL 2007).

Kompletna dezintegracija vodik peroksida završena je nakon 19 dana. Koncentracija analita bila je umanjena za $20 \%$ nakon 1 dana i za $50 \%$ nakon 7 dana. Najveći utjecaj na stabilnost analita pokazali su ioni $\mathrm{Fe}(\mathrm{III}), \mathrm{Mn}(\mathrm{II})$ i Co(II). Ioni $\mathrm{Fe}(\mathrm{III}) \mathrm{u}$ koncentraciji $200 \mu \mathrm{g} / \mathrm{dm}^{3}$ nisu pokazali značajniji utjecaj na raspad analita, međutim dodani u koncentracijama od 1000 i $2000 \mu \mathrm{g} / \mathrm{dm}^{3}$ pokazali su izrazit katalitički utjecaj pri čemu je dezintegracija analita završena za 5 dana.

Ioni mangana pokazali su katalitički efekt izražen u vremenu te je razlaganje analita uz dodatak 200, 1000 i $2000 \mu \mathrm{g} / \mathrm{dm}^{3} \mathrm{Mn}$ (II) iona bilo završeno za 10,8 i 7 dana. Utjecaj Co(II) iona bio je više izražen na početku reakcije, te je analit kompletno razložen za 10 dana uz dodatak 1000 i $2000 \mu \mathrm{g} / \mathrm{dm}^{3} \mathrm{Co}$ (II) iona.

$\mathrm{Cu}(\mathrm{II})$ ioni nisu pokazali izražen katalitički efekt u koncentracijama od $200 \mathrm{i}$ $1000 \mu \mathrm{g} / \mathrm{dm}^{3}$, ali u koncentraciji od $2000 \mu \mathrm{g} / \mathrm{dm}^{3}$ potpuno je potisnut signal analita. $\mathrm{Na}$ svim ispitivanim koncentracijama, Ni(II) ioni nisu pokazali jači utjecaj na raspad vodik peroksida. Kompletan raspad analita uočen je nakon 18 dana za 200 i 1000 $\mu \mathrm{g} / \mathrm{dm}^{3} \mathrm{Ni}(\mathrm{II})$ iona i nakon 16 dana u prisustvu $2000 \mu \mathrm{g} / \mathrm{dm}^{3} \mathrm{Ni}(\mathrm{II})$ iona.

$\mathrm{U}$ prisustvu iona $\mathrm{Zn}(\mathrm{II})$ i $\mathrm{Pb}(\mathrm{II})$ ne dolazi do ubrzavanja raspada vodik peroksida. Na svim ispitivanim koncentracijama iona raspad vodik peroksida se 